\title{
Geohazard assessment of the coastal zone - the case of the southern Baltic Sea
}

\author{
Grzegorz UŚCINOWICZ ${ }^{1, *}$, Tomasz SZARAFIN¹, Urszula PACZEK'1, \\ Mirosław LIDZBARSKI ${ }^{1}$ and Ewa TARNAWSKA ${ }^{1}$
}

1 Polish Geological Institute - National Research Institute, Marine Geology Branch, Kościerska 5, 80-328, Gdańsk, Poland

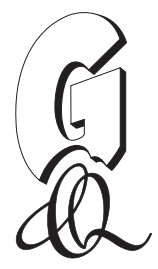

Uścinowicz, G., Szarafin, T., Pączek, U., Lidzbarski, M., Tarnawska, E., 2021. Geohazard assessment of the coastal zone the case of the southern Baltic Sea. Geological Quarterly, 2021, 65: 5, doi: 10.7306/gq.1576

Associate Editor: Tomisław Gołębiowski

Research by the Polish Geological Survey has been carried out along the southern Baltic coastal zone over a distance of $38 \mathrm{~km}$. The Baltic Sea is classified as non-tidal, and its southern coasts are built entirely of weakly lithified sedimentary rocks. These deposits form three main types of coast, namely cliffs, barriers and alluvial coasts (wetlands), with the research focusing on the first two. Methods including remote sensing, mapping (geological, hydrogeological), offshore survey (bathymetric and geophysical measurements), laboratory analyses and modelling revealed a number of natural hazards. These are, respectively: (1) permanently occurring hazards, causing material damage such as: landslides, coastal erosion and seabed erosion; (2) incidental hazards such as dune breakage and storm surge overflow and (3) hypothetical threats that may occur in the future, such as hydrogeohazards defined here as flooding resulting from groundwater level rise or more rarely, earthquake threats.

Key words: coastal measurements, northern Poland, land-sea interaction, coastal geodynamics.

\section{INTRODUCTION}

Geohazards (including marine geohazards) encompass an extensive range of features, processes, and events related to geology (Yonggang et al., 2016; Culshaw, 2018) and as such they must be included in all adaptation-related and planning activities (Didier et al., 2019), and interest in natural threats has grown in recent years (Camargo et al., 2019). Studies of threats are conducted around the word in different geographical conditions. This determines the range and scope of interest from local to broad, needing a multi-disciplinary approach. In common understanding, natural hazards are identified in particular with endogenic processes such as volcanic eruptions and earthquakes, or exogenic ones, as in mountainous areas where various types of mass movement can be expected, and valley areas where threats related to floods and related processes can be forecast. Therefore, natural hazards occur in regions where geodynamic phenomena may take place and are often associated with human pressure on land development. One kind of location that combines these features comprises the coastal zones of oceans and seas, including the Baltic Sea. Rising hu-

\footnotetext{
* Corresponding author, e-mail: grzegorz.uscinowicz@pgi.gov.pl Received: July 13, 2020; accepted: November 6, 2020; first published online: January 21, 2021
}

man interest in, and pressure from, unfavourable natural processes have been documented from at least medieval times (Mörner, 2008; Ryabchuk et al., 2012; Uścinowicz et al., 2013; Piotrowski et al., 2017). In modern times, issues related to natural geological hazards have been extensively studied (Zeidler, 1995; Uścinowicz et al., 2004; Valdmann et al., 2008; Harff and Mayer, 2011; Spiridonov et al., 2011; Lidzbarski and Tarnawska, 2015; Palginõmm et al., 2018; Moskalewicz et al., 2020; Paprotny et al., 2020). In recent years the Polish Geological Survey has carried out detailed mapping of the southern Baltic Sea coastal zone together with geohazard identification, of which the results described here are part. Studies of the geological structure and concerning predictive models of coastline change have been published earlier (Uścinowicz et al., 2014, 2017, 2019; Uścinowicz and Szarafin, 2018) and complement the results described here. The complementary approach involved the requirements of stakeholders, local groundwater managers and users, entities responsible for environmental protection and coastal zone management and all those who consider coastal areas as a shared environment.

Most of the studies noted above relate to individual geohazards. Our study by contrast aims to describe the occurrence of all existing and potential natural, geological hazards (geohazards) identified along a significant part of the Polish section of the southern Baltic Sea coast. The area under discussion enables discussion of the various natural hazards occurring in different geographical and geological conditions (i.e. lowlands barrier type coast, morainic upland - cliff coast). It is also an area of intense human pressure, especially as regards tourism and agriculture. 


\section{STUDY AREA}

The study area is located on the southern Baltic coast (northern Poland), and extends east-west along a $38 \mathrm{~km}$ stretch of coastline between $17^{\circ} 49^{\prime} 16^{\prime \prime}$ and $18^{\circ} 23^{\prime} 12^{\prime \prime} \mathrm{E}$. The area reaches $2 \mathrm{~km}$ offshore and $2 \mathrm{~km}$ inland, its geology being mapped in detail as part of wider research. Geographically, the area encompasses two different morphological units: a lowland where a barrier is developed and an upland bordered by a steep cliff (Fig. 1A). The beach width reaches several tens of metres and its profile varies depending on the season. The area is limited to the north by the sea, the seabed gradually deepening to the north or north-east to a depth of $\sim 15 \mathrm{~m}$, the isobaths being more or less parallel to the shore. There are two, sometimes three, sandbars close to the shore in depths of up to $5 \mathrm{~m}$. Their elevation is between 1 and $4 \mathrm{~m}$. To the south and east the area under discussion is limited by a morainic upland while the western part continues as a coastal lowland covered by dunes (Uścinowicz and Szarafin, 2018).

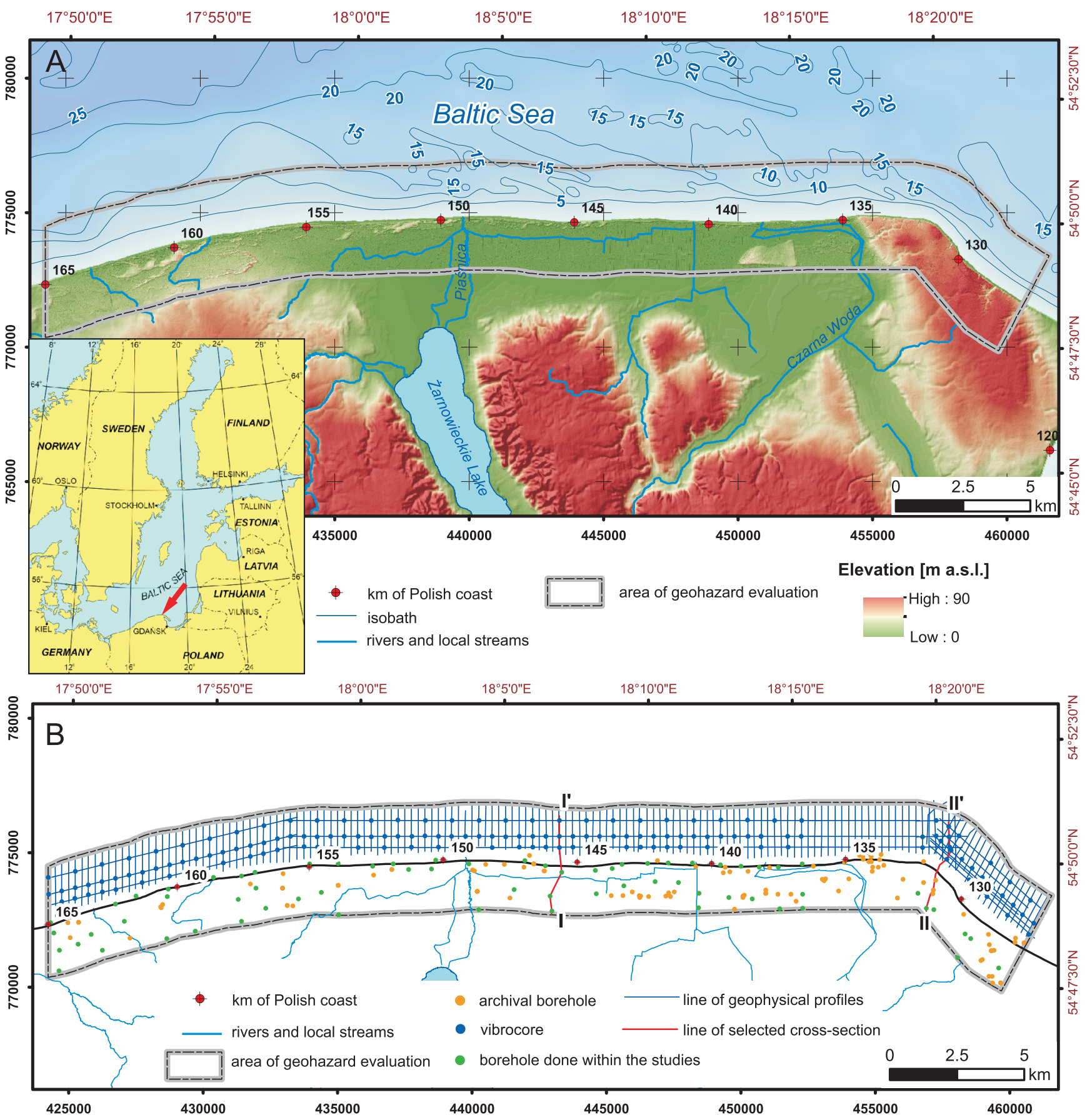

Fig. 1. Location of the study area (A) and map documenting the geological studies undertaken (B)

Source of bathymetry - Polish Geological Institute - National Research Institute, source of DTM's - Military Center of Geodesy and Remote Sensing and IT system of the Country's Protection Against Extreme Hazards (ISOK) 
The geological setting of this area is closely linked with its morphological structure. The low-lying area (the western and central parts of the study area) is built of fluvioglacial sands overlain by Holocene lacustrine and biogenic deposits - fine sand, mud, gyttja and peat. The barrier is narrow, ranging from several tens of metres to $400 \mathrm{~m}$ across. It consists of fine and medium sand overlain by aeolian dunes, which are not higher than $20 \mathrm{~m}$. Locally, peat is exposed on the beach or is present under a thin cover of beach sand. In general, the thickness of the marine sand barrier does not exceed $10 \mathrm{~m}$. The eastern part is a morainic upland with its adjacent cliff. It is built of Miocene sand and silt with brown coal interbeds. Directly above lies fluvioglacial sand and gravel, overlain in some places by a thin layer of till. Locally, on the surface of the upland, aeolian sheets with a thickness of up to $3 \mathrm{~m}$ occur. The geology of the lowland and the morainic upland have several published descriptions (Pawłowski, 1922; Rudowski, 1965; Uścinowicz et al., 2014, 2017; Moskalewicz et al., 2016; Uścinowicz and Szarafin, 2018; Widera, 2019) and may be illustrated by geological cross-sections (Fig. 2).

Geological studies of the inland area have been conducted for decades, though until recently the offshore area remained relatively unstudied. The description below is based on the work of the Polish Geological Survey, and is the first to describe in detail the offshore part of the coastal zone.

The simplified geological division described above continues offshore. Seismoacoustic records correlated with core profiles allowed distinction of four lithological units building the sea floor. These are: Holocene marine sand, Holocene lagoon-lacustrine deposits, Pleistocene glacial and fluvioglacial deposits, Pleistocene ice-marginal lake deposits.

The Pleistocene profile is dominated by calcareous fluvial medium- and coarse sand and sandy gravel, rarely fine and very fine sand. Till also occurs in the Pleistocene succession. The Pleistocene top is located at depths from $0 \mathrm{~m}$ to $\sim 17 \mathrm{~m}$ below the sea floor (b.s.b.). The till top is located at a depth of 1.2 to $4 \mathrm{~m}$ (b.s.b.). Pleistocene outcrops are locally present outside the sandbar zone in the north-central part of the study area.

Ice-marginal lake deposits (fine sand and silt) occur in the northwestern part of the study area. They lie above older, genetically different Pleistocene deposits; a very clear boundary may be observed between them in the seismoacoustic record. The erosionally levelled top of the ice-marginal deposits is located at depths of 15-17 m (b.s.b.), and their thickness reaches $5 \mathrm{~m}$.

Holocene lagoon-lacustrine deposits built of fine sand, silt, clay, gyttja, peat containing fragments of freshwater mollusc

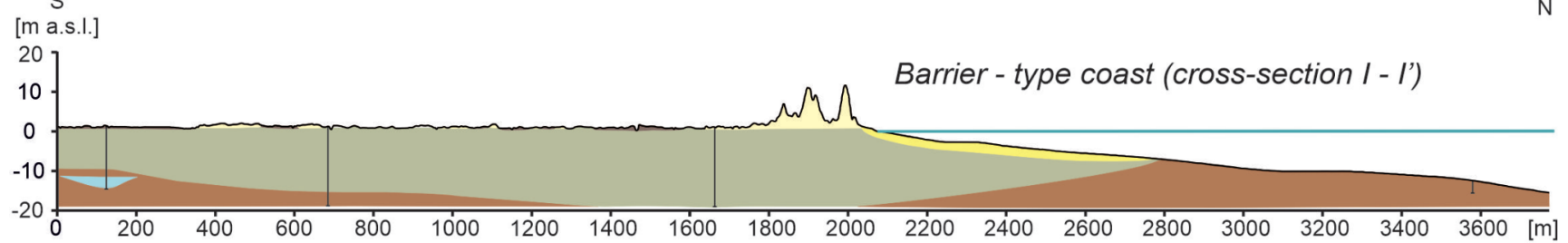

$S$
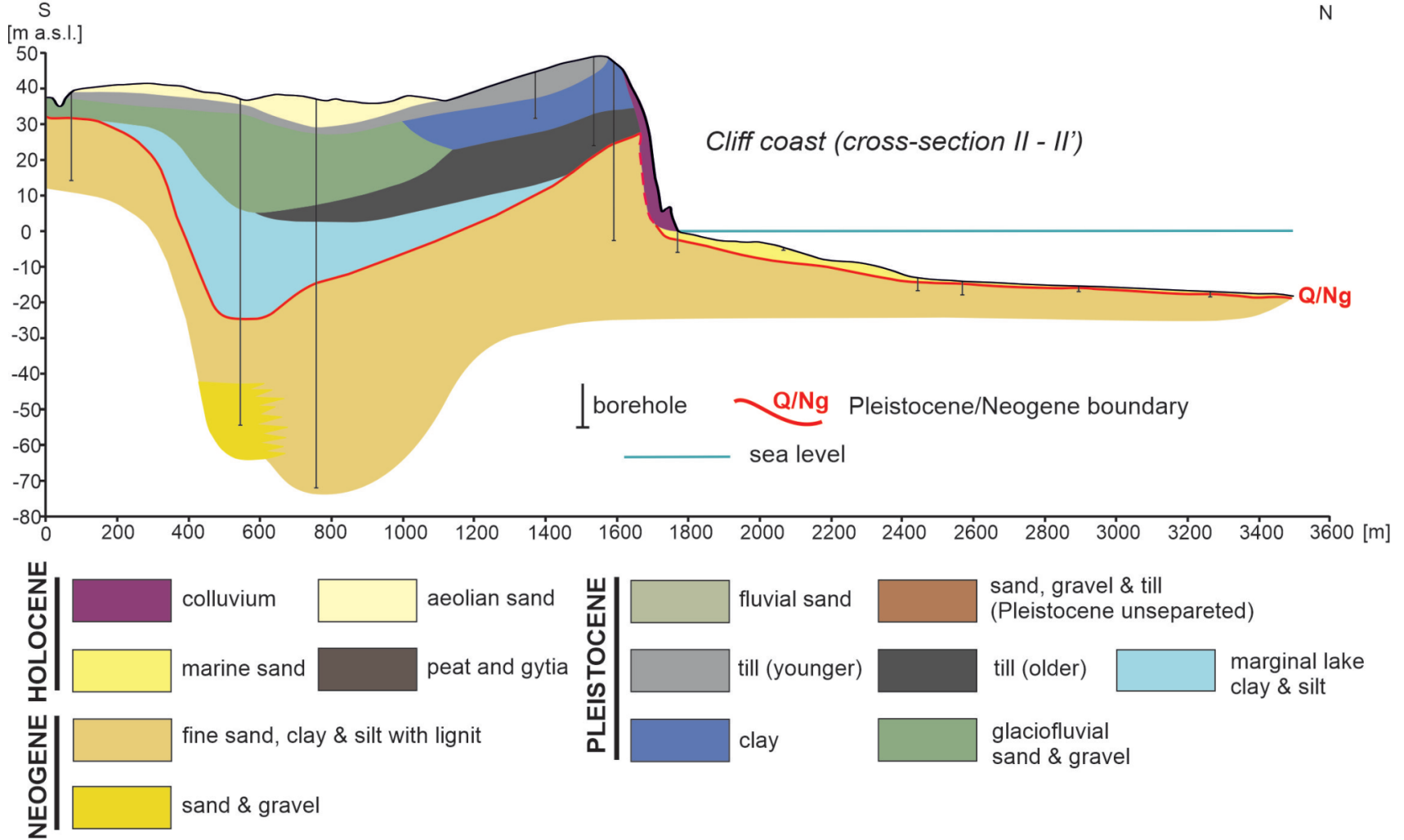

sand, gravel \& till (Pleistocene unsepareted)

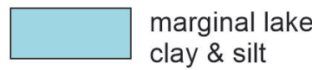

glaciofluvial sand \& gravel

Fig. 2. Selected geological cross-sections illustrating

the geological conditions of lowland (barrier - type coast) and upland (cliff coast) areas

The line of cross-section can be found on Figure 1B (Polish Geological Institute - National Research Institute materials) 
shells and layers of organic matter occur in the western part of the study area. The age of the peat top ranges from $\sim 12,000$ to $\sim 9,000$ cal BP. The deposits described lie on older Pleistocene strata. In the sediment cores, there is a clear erosional contact between the fresh water lake and marine sands in the form of a marine shell layer. The lagoon-lacustrine deposits are max. $2 \mathrm{~m}$ thick.

The Holocene marine sand, composed mainly of non-calcareous fine sand with some medium sand, containing layers of organic matter and fragments of marine mollusc shells, lies on an erosional surface of Pleistocene age. The Holocene and Pleistocene units are separated by a clear erosional boundary in the form of gravel and coarse sand layer. The thickness of the marine sand ranges from a few centimetres to $\sim 10 \mathrm{~m}$.

\section{MATERIALS AND METHODS}

The varied methods used enabled identification of processes that may be considered as natural threats (Fig. 1B and Table 1).

\section{REMOTE SENSING ANALYSIS}

A digital terrain model (DTM) based on laser airborne scanning with a resolution (pixel size) of $0.5 \times 0.5 \mathrm{~m}$ was analysed using various geoprocessing techniques. Parameters affecting the clarity and readability of the digital model were adjusted; these included colour scale, contrast and contours. GIS-based features - maps of slope (gradient of maximum changes in z-value), a shaded relief map and a set of multi-temporal digital terrain models from raster surfaces were created. These features were later used for morphological analysis including general delimitation of the main morphological patterns (edge and foot of the cliff, boundaries of landslides, dune edges, depressions between dunes, etc.). The source of the DTMs was the Maritime Office in Gdynia where 8 points $/ \mathrm{m}^{2}$ were scanned in a LIDAR survey. A second source was the IT system of the Country's Protection Against Extreme Hazards (ISOK) where 4 points $/ \mathrm{m}^{2}$ were scanned.

The spatial analyses were also made with the use of the oldest available cartographic materials - German topographic maps at 1:25,000 scale, drawn approximately at beginning of the 20th century - Messtischblatter: 135-Wittenberg (1875), 136-Dembek (1875), 137-Ostrau (1875); 138-Rixhof (1908). These maps served as the oldest available reliable comparative material to study coastline changes.

\section{FIELDWORK}

Fieldwork was conducted to refine interpretation of the geological structure. Cartographic fieldwork (geological, hydrogeological and landslide mapping) is crucial for verification of indirect analysis (i.e. remote sensing). Fieldwork enabled verification of landslide boundaries interpreted from maps and digital models as well as assessment of the state of the coast, including existing forms of shore protection. Preparation of accurate geological maps enables linking of the geological structure of the analysed coast with its susceptibility to various geohazards. The fieldwork included drilling 71 boreholes 15 to $25 \mathrm{~m}$ deep, and $26 \mathrm{~km}$ of electrical resistivity profiling for interpolation between the boreholes. This allowed definintion of the geologically and morphologically significant boundaries of the coastal area. The area investigated was geologically mapped at scale 1:10,000.

\section{HYDROGEOLOGICAL MAPPING}

Hydrogeological analysis concerned the occurrence and circulation of groundwater in the coastal zone and establishing the relationship of groundwater with surface waters. The analysis involved: collecting and verifying archival data; field mapping to spatially assess hydrogeological and hydrological conditions; developing analytical and digital models of the hydrogeological conditions. The predictive hydrogeohazard model was developed based on the occurrence of the first aquifer, assuming a $1 \mathrm{~m}$ sea level rise.

ModFlow 2000 software were used for the modelling. The hydrogeological conditions were schematized by means of LPF (Layer Property Flow), and PCG2 (Preconditioned Conjugate-Gradient) was used to approximate derivatives in the finite difference method. The research area was discretized with a $100 \times 100$ m grid, which gave 30,044 computational blocks.

Due to the heterogeneous recognition of hydrogeological conditions and the small amount of data on deeper aquifers, a model was developed based on one model layer, which included Pleistocene and Holocene units remaining in hydraulic contact with each other in most of the research area. They constitute the main water circulation system, especially in the coastal zone. The boundaries of the model in the northern and eastern parts were based on the Baltic Sea coastline, while the southern and western boundaries were determined along selected grid lines. A Constant Head Boundary (type I) was assigned for all boundaries. Major groundwater intakes and the infiltration supply were simulated using a Well Recharge condition (type II). Rivers and major sections of drainage ditches were defined as a condition of type III (River). The value of lat-

Methods and analyses used to identify and describe the natural processes

\begin{tabular}{|l|c|c|c|c|c|}
\hline \multicolumn{1}{|c|}{ Geohazard } & \multicolumn{5}{|c|}{ Method of geohazard evaluation } \\
\hline & $\begin{array}{c}\text { Remote sensing and } \\
\text { spatial analyses }\end{array}$ & $\begin{array}{c}\text { Field } \\
\text { works }\end{array}$ & $\begin{array}{c}\text { Hydrogeological } \\
\text { modelling }\end{array}$ & $\begin{array}{c}\text { Offshore } \\
\text { survey }\end{array}$ & $\begin{array}{c}\text { Laboratory } \\
\text { analyses }\end{array}$ \\
\hline Landslides & $\mathrm{x}$ & $\mathrm{x}$ & & & $\mathrm{x}$ \\
\hline Coastal erosion & $\mathrm{x}$ & $\mathrm{x}$ & & $\mathrm{x}$ & $\mathrm{x}$ \\
\hline Seabed erosion - sand deficit & & $\mathrm{x}$ & & & \\
\hline Dune breakage and storm surges & $\mathrm{x}$ & $\mathrm{x}$ & $\mathrm{x}$ & & \\
\hline Hydrogeohazard & $\mathrm{x}$ & $\mathrm{x}$ & & \\
\hline
\end{tabular}


eral supply over the entire area of the groundwater flow was estimated using analytical methods before starting the model calculations. This was important for model verification and calibration. The correctness of the mathematical model developed was also checked by comparing the measured water level and course of contour-lines shown in archival materials with calculated values, and by analysing the water cycle balance and comparing measured individual components (evaporation, infiltration, drainage, outflow to the sea, etc.) with the values calculated during the preparation of the conceptual model.

\section{OFFSHORE SURVEY}

Bathymetric measurements were carried out using a multi-beam sonar (Geoswath GS4+, Kongsberg - frequency versions: $500 \mathrm{kHz}$ ) and were comprised profiles parallel and perpendicular to the shoreline at intervals that ensured almost full coverage of the bottom in the open sea zone.

The measurements were carried out from the deck of a motorboat in a water depth range from $18 \mathrm{~m}$ to $\sim 1.5 \mathrm{~m}$. In the depth zone from $1.5 \mathrm{~m}$ to the shore (in practice to the elevation $0.5 \mathrm{~m}$ a.s.I.) the survey was carried out manually using a RTK-GPS receiver.

A seismoacoustic survey using a sub-bottom profiler [Meridata High-deffinition SBP - chirp transducer (2-9 kHz)] was carried out in profiles perpendicular to the shore with profiles spaced $250 \mathrm{~m}$ apart, and 3 profile strings parallel to the shore. The seismoacoustic profiling constrained the geological structure of the area to a depth of $\sim 20 \mathrm{~m}$ below seabed. These measurements were carried out to a depth of $\sim 4 \mathrm{~m}$, in part to estimate the thickness of marine sand.

A sonar mosaic was also made, with profiling along on the same lines as the seismoacoustic survey, using a S-150 Sonartech side scan sonar. The frequency for the sonar survey was set to $400 \mathrm{kHz}$ and the maximum range for $140 \mathrm{~m}$. This brought information on the nature of the bottom surface and constrained the boundaries of the marine sand cover.

Collection of sediment cores using a vibrocore system (VKG-03/04) complemented the geophysical data. 150 sediment cores each $\sim 3 \mathrm{~m}$ long and 150 seabed sediment samples were collected.

All bathymetric data was post-processed to create a digital terrain model (DTM) with a resolution of $5 \times 5 \mathrm{~m}$ and from this a bathymetric map was made. The sonar data was assembled into a mosaic.

Geodetic measurements related to the marine survey were made in the Polish coordinate system PI-1992 (EPSG 2180). A navigation system with a position measurement accuracy better than $0.5 \mathrm{~m}$ was used.

\section{LABORATORY ANALYSIS}

In the laboratory, the cores and surface sediment samples were macroscopically described, and samples were taken from each layer based on macroscopically visible differences in grain size distribution.

\section{GRAIN SIZE ANALYSIS}

To determine the grain size distribution of the sediments, the Udden-Wentworth scale (Wentworth, 1922), modified by the Polish Geological Survey, was used. This scale distinguishes 5 basic classes: $<0.0039 \mathrm{~mm}(>8 \Phi)$ clay, 0.0625-
$0.0039 \mathrm{~mm}(4-8 \Phi)$ silt, 2-0.0625 mm (-1-4 Ф) sand, 64-2 mm $(-6--1 \Phi)$ gravel, >64 (<-6 $\Phi) \mathrm{mm}$ boulder.

Grain size analysis was by sieving method or by laser diffraction, depending on macroscopic estimate of grain size. With a predominance of grains $>0.063 \mathrm{~mm}$ in diameter, sieving was used, while finer samples (and the fines component of sand-dominated samples) were analysed by laser.

Where sediment aggregates were observed, the sediment was washed through a sieve of a $0.063 \mathrm{~mm}$ mesh diameter, followed by dry sieving and laser analysis of any fines.

$$
\text { MEASUREMENT OF }{ }^{137} \text { CS ACTIVITY }
$$

Measurements of ${ }^{137} \mathrm{Cs}$ activity in the cores allows estimation of the thickness of the present-day mobile layer of sediments, transported by currents and waves during storms. Caesium 137 is an artificial radionuclide, which entered the environment after 1945 as a result of nuclear weapons testing and accidents at nuclear power plants. Its presence in deposits shows the thickness of the layer that has undergone redeposition during the last few decades (Uścinowicz et al., 2014; Bunke et al., 2019).

Measurements of ${ }^{137} \mathrm{Cs}$ activity were carried out at the Institute of Physics of the Silesian University of Technology in Gliwice. The Caesium 137 activity was measured in 30 samples from 4 cores, by means of gamma-ray spectrometry. All samples were first dried at $60^{\circ} \mathrm{C}$ until their mass was constant. Afterwards samples were carefully mixed and homogenised and placed in $0.65 \mathrm{dm}^{3}$ Marinelli beakers closed tightly. The ${ }^{137} \mathrm{Cs}$ isotope activity was measured on the basis of a $661.7 \mathrm{keV}$ gamma peak. The detection limit was equal to $0.5 \mathrm{~Bq} / \mathrm{kg}$. The reference IAEA-375 (distributed by the Laboratory of Seibersdorf IAEA, Vienna, Austria) was used as a standard for ${ }^{137} \mathrm{Cs}$ activity. Finally, the ${ }^{137} \mathrm{Cs}$ activities in the samples were decay-corrected to the date of sampling and the result was expressed in $\mathrm{Bq} / \mathrm{kg}$.

\section{RESULTS}

\section{LANDSLIDES}

The most obvious natural threat in the area under discussion concerns various mass wasting processes, observed over the entire, $9 \mathrm{~km}$ cliff section. The survey documented continuous mass movements at different scales - from simple to genetically and morphologically complex forms. The landsliding is repetitive in relation to scale. At the western end of the area, there are alternating zones of increased landslide vulnerability and zones with lower landslide potential. The exact number of landslides varies, within the dynamic system of the coastal zone. Adjacent landslides can merge as a result of slope processes, and smaller forms can be formed within larger ones. One may thus talk about landsliding zones, or a continuous occurrence of various mass wasting movements throughout the entire cliff section. The observations made are the result of ongoing work (Uścinowicz et al., 2014, 2017; Lidzbarski and Tarnawska, 2015; Uścinowicz and Szarafin, 2018).

The most active and devastating landslide, located in the western most part of the upland (134.25-134.50 km), has been reshaped and covered with a heavy hydrotechnical construction which is $235 \mathrm{~m}$ long and nearly $30 \mathrm{~m}$ high. The construction consists of four levels/steps secured on the outer side by blocks of rock which are enhanced with a steel mesh. In the adjacent landslide to the east. the slope has been reduced and the foot of the cliff is protected with a seawall (Fig. 3). Nevertheless, even 
these measures did not stop the mass movements, which subsequently became reactivated (Fig. 4).

Landslides are located over $5.2 \mathrm{~km}$ of the $9 \mathrm{~km}$ coastal section, which corresponds to $69 \%$ of the upland's edge. Some of these, especially in the area of Jastrzębia Góra and Rozewie (between 130 and $135 \mathrm{~km}$ ), directly threaten urban (Fig. 5) and navigation infrastructure.

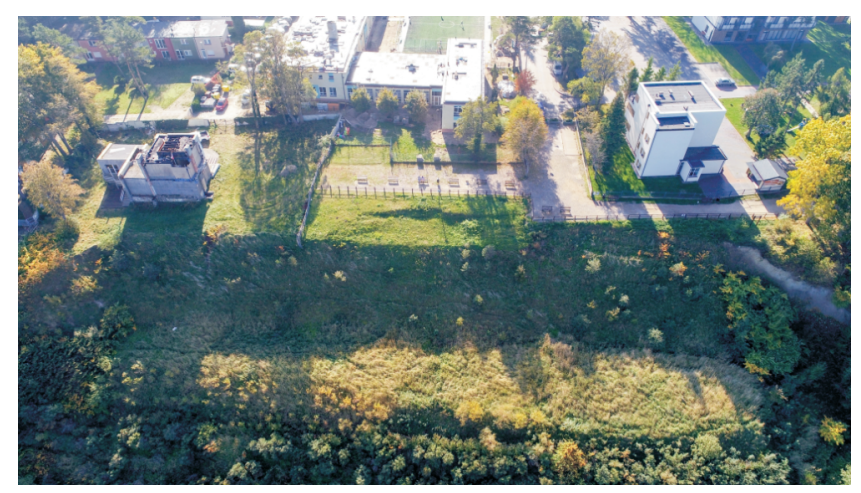

Fig. 3. Reclaimed and partly reactivated landslide at the Jastrzębia Góra resort (phot. M. Olkowicz)

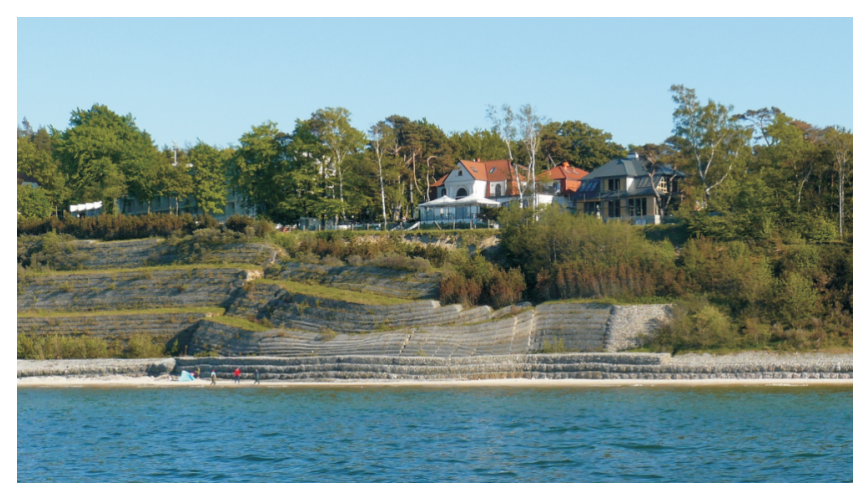

Fig. 4. Protective construction failure (phot. G. Uścinowicz)

\section{COASTAL EROSION}

Comparison of the oldest available and reliable topographic maps and modern digital terrain models reveals areas of significant coastal erosion. Such areas can be found in the vicinity of Chłapowo $(127.0-130.5 \mathrm{~km})$ between Jastrzębia Góra and Karwia (135.0-138.5 km), the villages of Karwia and Dębki (144.0-145.5 km of coastline) (Fig. 6) and in the vicinity of Lubiatowo $(163.0 \mathrm{~km})$. The first of these is associated with a cliff section while the rest are linked with a barrier type coast. The total shoreline displacement in the area of Chłapowo is up to $70 \mathrm{~m}$, while the area Jastrzębia Góra-Karwia reveals that the shoreline has shifted landward by 125-150 m. A similar situation is visible in the other areas i.e., Karwia-Dębki - up to $125 \mathrm{~m}$ and Lubiatowo - up to $75 \mathrm{~m}$. This shows that barriers here are much more prone to erosion than cliffs.

$22.5 \mathrm{~km}$ of coastline is under erosion, $59 \%$ of the area studied.

\section{SEABED EROSION - SAND DEFICIT}

Coastal erosion is closely related to the processes occurring at the sea floor, especially in the shallow water area, where the underwater slope in the area discussed has a slope rarely exceeding $2^{\circ}$. In the vicinity of Jastrzębia Góra the layer of marine sands lies on an erosion surface of the Pleistocene and Neogene/Paleogene deposits. This layer is discontinuous and its thickness ranges from a few centimetres to $5 \mathrm{~m}$. The thinnest cover comprises residual coarse-grained deposits with numerous boulders. In these areas there is insufficient sand to enhance the sea shore. For the purpose of this study, a thickness of $2 \mathrm{~m}$ was assumed as a minimum value with respect to hazard. This value is consistent with the results obtained of ${ }^{137} \mathrm{Cs}$ analyses, reflecting the mobility of the sand layer (Uścinowicz et al., 2014). The ${ }^{137} \mathrm{Cs}$ activity in the samples was low, ranging from concentrations below detection limits in the lowermost samples (in the range of $1.2-2.0 \mathrm{~m}$ b.s.b.) to $4.19 \pm 0.21 \mathrm{~Bq} / \mathrm{kg}$ in the surface part of the cores. This means that in the study area a layer of sand at least $2 \mathrm{~m}$ thick can be mixed or moved. If a $2 \mathrm{~m}$ layer of sand is



Fig. 5. Landslides on a slope map in the vicinity of threatened infrastructure 




Fig. 6. Area of intense marine erosion (vicinity of the $145 \mathrm{~km}$ of Polish coastline)

Source of DTM - ISOK

displaced, the older substrate (Pleistocene and/or Neogene) is hence periodically exposed and more intensely eroded. The lack of a marine sand cover on the seabed facilitates the erosion of the substrate and may cause a lack of sandbars, which hastens the erosion of the sea shore.

Deficit zones are places of increased erosion of the seabed and the adjacent coast. A good example of this situation is the region of Jastrzębia Góra and Karwia, where both the cliff section (Fig. 7) and the barrier is eroded. The barrier type coast is much more vulnerable to marine erosion than are cliffs, which is why the observed shoreline retreat is much larger and better visible there. This, in turn, creates pressure to use further forms of coastal protection that raises new problems (Fig. 8).
The largest sand deficit areas adjacent to the shore are located in sections between $128.5-129.5 \mathrm{~km} ; 133.0-134.5 \mathrm{~km}$; $137.5-140.0 \mathrm{~km} ; 145 \mathrm{~km} ; 150.0-152.0 \mathrm{~km} ; 157.0-158.5 \mathrm{~km}$; and $161.5-163.0 \mathrm{~km}$. The total area of deficit identified is $33.2 \mathrm{~km}^{2}$. This area is bounded by the shoreline and the boundaries of the study area ( $2 \mathrm{~km}$ offshore).

\section{DUNE BREAKAGE AND STORM SURGE OVERFLOWS}

Flooding of low-lying areas is another potential natural hazard in the area. One source of flooding is storm surges causing

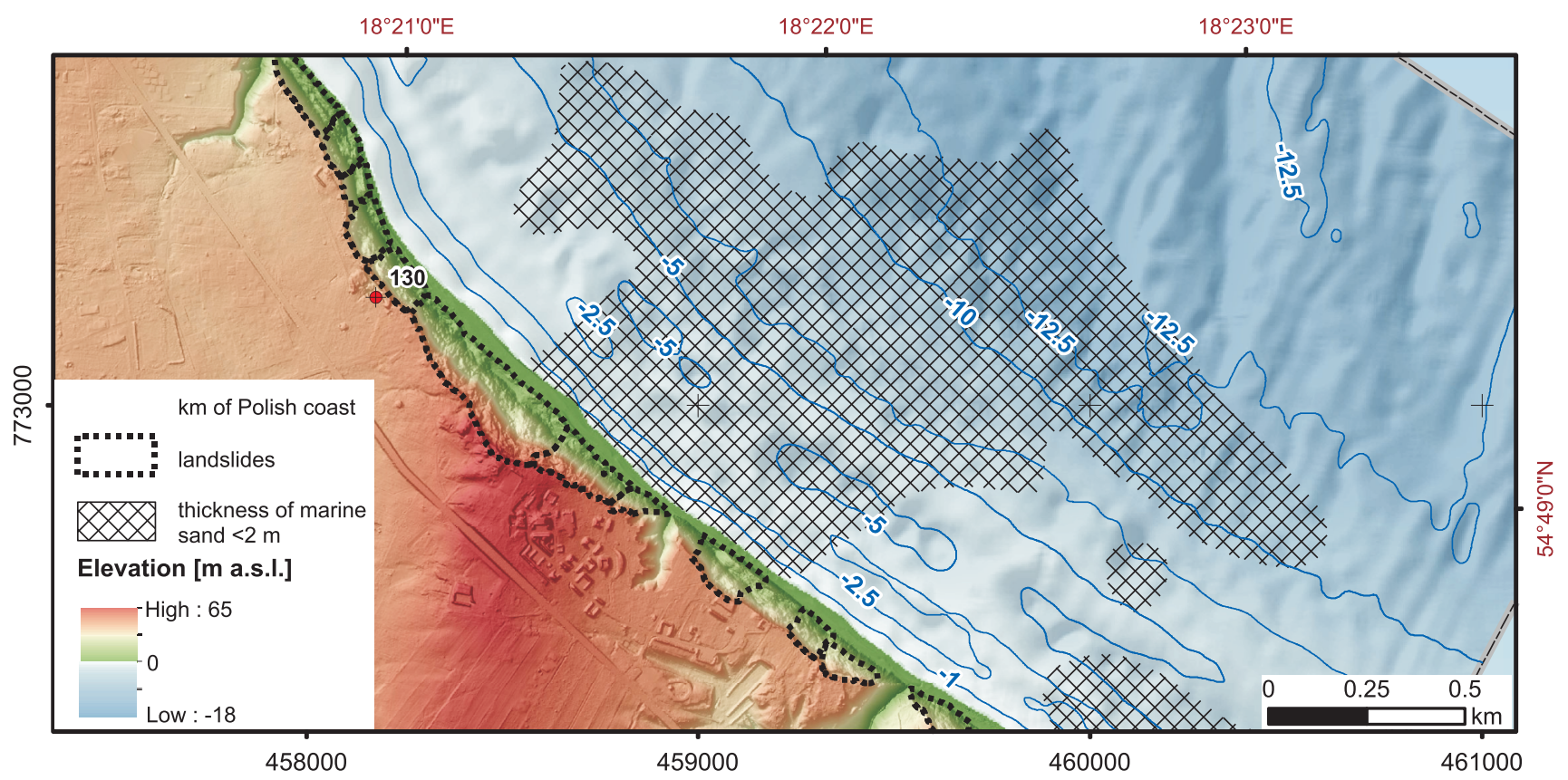

Fig. 7. Sand deficit in front of a set of complex landslides

Source of bathymetry - Polish Geological Institute - National Research Institute, source of DTM - ISOK 
dune breakage. The barrier part of the coast between 135 and $143.5 \mathrm{~km}$ is the most exposed to this type of threat. Places of deflation depression as well as human-made passages across the dunes are the most liable to breaks (Fig. 9). Such a process concerns the extremely low and narrow barrier in the area of Karwia, where the dunes do not exceed $5 \mathrm{~m}$ in height and where the inflow of seawater encounters little obstacle. This situation has changed significantly as a result of major coastal protective work. A flood embankment and seawall have been raised in the vicinity of Karwia and Dębki. These constructions extend between 135 and $143.5 \mathrm{~km}$ of coast.

A second source of flooding is the potential inflow of seawater through river outlets: of the Piaśnica, Czarna Woda and other minor streams and rivers. Due to storm waves, river flow near the outlet can be stopped or even turned back to the land, causing flooding. This phenomenon may be combined with a temporary rise of the groundwater table flowing towards the drainage base, which is the sea, rivers and local streams.

In the area discussed, the land most exposed to flooding does not exceed $1 \mathrm{~m}$ a.s.l. Anthropogenic factors associated with land development (e.g., neglect of drainage ditches) predispose an area to this type of threat.

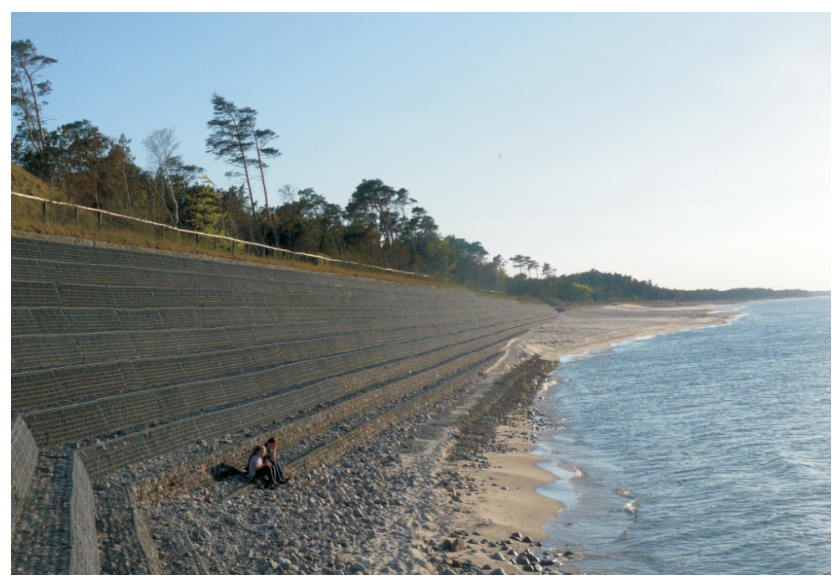

Fig. 8. Lack of beach in front of a seawall

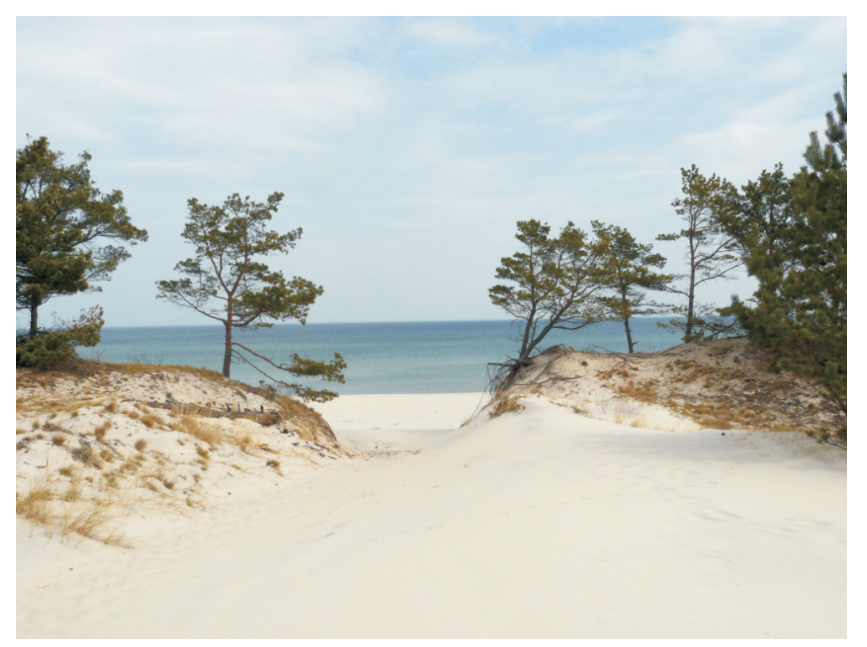

Fig. 9. Dune gap - a passageway for seawater

Photo taken on a barrier type coast (phot. G. Uścinowicz)

\section{HYDROGEOHAZARD}

Sea level rise can also particularly affect aquifers, especially their dynamics. A model assuming an increase of sea level of $1 \mathrm{~m}$, as widely predicted, was adopted for simulation. Various scenarios have been made for the southern Baltic, projecting an increase in sea level by 2100 from $\sim 0.5 \mathrm{~m}$ to $>1 \mathrm{~m}$ (Meier et al., 2004; Staud et al., 2006). The worst-case scenario assuming an increase of $1 \mathrm{~m}$ has been adopted in this paper. This scenario, analysing the change in hydrodynamic conditions with drainage base levelled to $1 \mathrm{~m}$ a.s.l. showed far-reaching changes not only in groundwater dynamics, but also in the hydrographic system. Depending on the parameters of the aquifer system and its distance from the Baltic Sea, which is the main drainage base, the groundwater level will rise. As a consequence, significant floodplains are projected to occur in the river valleys and coastal low-lying areas, and some areas will be permanently flooded with groundwater (Fig. 10). Given these assumptions, an area of $27.4 \mathrm{~km}^{2}$ may be flooded, which is $37 \%$ of the area investigated.

Increasing the drainage base level in the lowland will reduce the amount of water involved in circulation by $\sim 15 \%$. By contrast the intensity of outflow from the uplands into the Baltic Sea will increase. Consequently, groundwater outflows at the cliff foot and in the colluvium of landslides should also be expected to increase by $\sim 10 \%$.

\section{EARTHQUAKES?}

Brief mention of the possible impact of an earthquake on this coastal section has been made (Uścinowicz et al., 2019), and is relevant to the potential geohazards of the region.

The southern Baltic region is traditionally regarded as aseismic. However, the occurrence, on September 21, 2004, of a series of tremors of magnitude 4.7-5.2 in the Kaliningrad region (Wiejacz, 2006; Assinovskaya and Ovsov, 2008) means that this type of potential threat exists.

It may be linked to an event that influenced the coast in the vicinity of the Rozewie headland. The Rozewie cliff by the beginning of the 20th century was protected by several types of protective construction and since then was considered inactive. Mass movements were unexpectedly activated in April 2005 after $\sim 100$ years of stability. The event in 2005 resulted in damage to the seawall at the base of the cliff. This renewal of landslides took place 6 months after the earthquake in the Kaliningrad region, which may have weakened the structure and stability of the slope. Rainfall in autumn 2004 and frost in the winter of $2004 / 2005$ as well as the snow melt and spring precipitation might have caused further disturbance.

Summaries of these natural hazards are shown in Table 2 and Figure 11.

\section{GEOHAZARD ASSESSMENT}

To assess the importance ("weight") of each phenomenon some fundamental questions should be answered. Is the phenomenon real or hypothetical? Did the phenomenon occur in the last 20 years? Is the phenomenon permanent or incidental? Did the phenomenon cause material damage? Have attempts been made to prevent the phenomenon? In answering these questions, we are able to naturally rank the phenomena described above (Table 3). Answers to each question can be ranked from 1 to 0 points, and overall assessment can demonstrate whether the threat discussed may be considered as of high, moderate or low importance. 




Fig. 10. Forecast of area threatened by floods as a result of groundwater level rise

Source of DTM - ISOK

Table 2

A quantitative summary of the threats described

\begin{tabular}{|l|c|c|}
\hline \multirow{2}{*}{\multicolumn{1}{|c|}{ Geohazard }} & \multicolumn{2}{c|}{ Units } \\
\cline { 2 - 3 } & Length [km] & $\%$ \\
\hline Coastline under erosion & 22.5 & 59 \\
\hline Landslide coverage of the cliff coast & 5.2 & 69 \\
\hline & Area $\left[\mathrm{km}^{2}\right]$ & $\%$ \\
\hline Areas of sand deficit & 33.2 & 43 \\
\hline Areas potentialy threatened by flood & 27.4 & 37 \\
\hline
\end{tabular}

\section{DISCUSSION}

Interaction of the natural hazards identified plays an important role, generally making them more serious. Intensified marine erosion in areas of a deficit of sand on the beach and offshore provides a good example. This issue is not limited to the southern Baltic cliff coast, where these relations have been recorded (Uścinowicz et al., 2019), but also in relation to other coasts (Lee, 2008; Orviku et al., 2013; Earlie et al., 2018). In such instances a sufficiently thick layer of sand on the seabed is of fundamental importance for limiting erosion processes.

However, not all coast sections are eroded, erosional zones being separated by accumulative sections (Furmańczyk and Musielak, 2002; Uścinowicz and Szarafin, 2018). The relationships between these sections, their stability or mobility, is only partly investigated and understood (Furmańczyk and Musielak, 1999, 2002).

This is the case to as regards a potential increase in groundwater level (hydrogeohazard), where the drainage base on the upland will be raised causing increased water outflow through the cliffs. As a result the rate of mass-wasting processes will increase. Meanwhile, the barrier-type coast will be exposed to destructive processes from two directions: increased marine erosion from the north and erosion of dunes from the south, where areas of permanent floodplain will be greater. The risk of ingress of salt water into aquifers and local groundwater intakes located near the coastal zone will also probably increase.

And finally, there is the potential for earthquakes. Earthquakes occurring in the past in the area of the Baltic Sea were caused by glacioisostatic movements (Mörner, 2004) and had significant magnitude. Nowadays, the Baltic Sea region is considered as a low-seismicity area. Nevertheless, earthquakes have occurred to a lesser extent in modern times with epicentres in the Kaliningrad and Tallinn regions (Assinovskaya and Ovsov, 2008; Spiridonov et al., 2011). Reoccurrence of this type of event cannot be excluded, with impacts on the coastal zone that may include the renewal of mass movements. Such situation has been reported from Alaska (Miller, 1960; Hansen, 1965) and from New Zealand (Lari et al., 2014).

The great majority of analyses in this study were based on contemporary work, the use of archival materials posed some methodological difficulties. Old topographic maps dating from the end of the 19th and the beginning of the 20th century were used to analyse coastline changes by comparison with the latest digital terrain models. To what extent are such maps are a useful and reliable source of information? These old German maps (Messtischblatt) in scale 1:25,000 are characterized by high level of details and accuracy by comparison with modern maps (Deng et al., 2017), and so provide reliable information concerning the coastal topography at the beginning of the 20th century, to help determine the general evolution of the study area. 

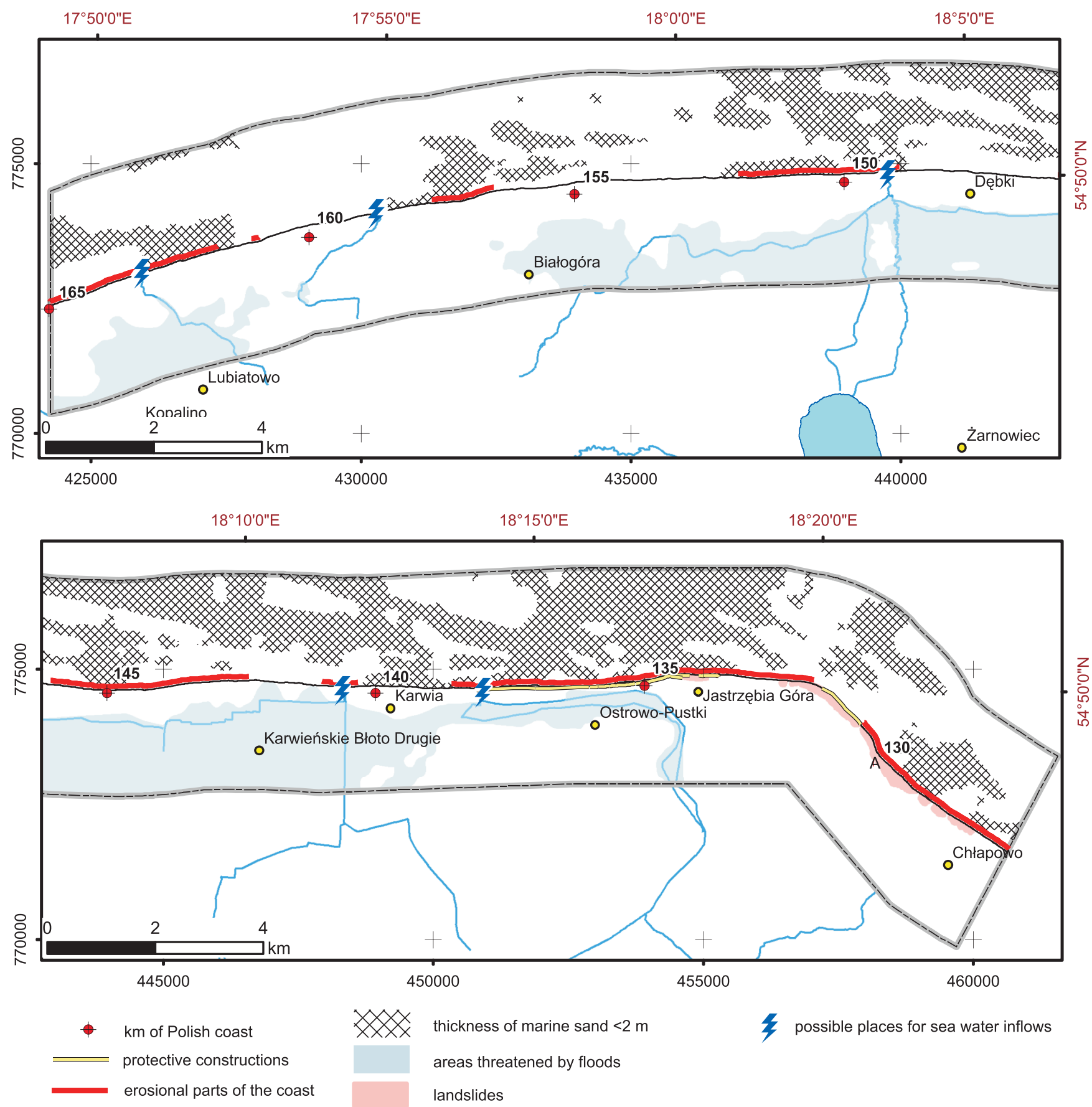

Fig. 11. Summary picture of the natural geological hazards identified

\section{CONCLUSIONS}

The natural hazards analysed in this study allowed the following conclusions:

- Landslides can be observed over the entire, $9 \mathrm{~km}$ cliff section. As a steep cliff coast is highly dynamic, it is most reasonable to talk about landsliding zones or of the continuous occurrence of various mass wasting movements throughout the entire cliff section.

- Significant sections of the studied coastline $(22.5 \mathrm{~km}$ in total) are undergoing coastal erosion. The eroded sections are related to offshore areas where sand deficit has been recognized. This phenomenon should be studied further in relation to accumulation/erosion changes along the coastline.

- Seabed erosion (sand deficit) can be observed over a significant part $\left(\sim 33 \mathrm{~km}^{2}\right)$ of the area studied and should be perceived as significantly influencing the whole coastal zone (both cliff and barrier).

- Dune breakage and storm surges are most likely in places of deflation depression, river outlets as well as artificial paths created by man. This process most concerns the extremely low and narrow barrier sections, where the inflow of seawater encounters only a slight obstacle. 
An assessment of geohazard potential (rank 1, 2 - low; 3, 4- moderate; >4 - high)

\begin{tabular}{|c|c|c|c|c|c|c|c|}
\hline Geohazard & Q1 & Q2 & Q3 & Q4 & Q5 & Rank & $\begin{array}{c}\text { Level of hazard } \\
\text { potential }\end{array}$ \\
\hline Landslides & real & yes & permanent & yes & yes & 5 & high \\
\hline Coastal erosion & real & yes & permanent & yes & yes & 5 & high \\
\hline Seabed erosion & real & yes & permanent & yes & partly yes & 4.5 & high \\
\hline $\begin{array}{l}\text { Dune breakage and } \\
\text { storm surge overflow }\end{array}$ & real & yes & incidental & yes & yes & 4 & moderate \\
\hline Hydrogeohazard & hypothetical & no & $\begin{array}{c}\text { could } \\
\text { be permanent }\end{array}$ & no & no & 1 & low \\
\hline Endogenic hazards & hypothetical* & yes & $\begin{array}{c}\text { could } \\
\text { be incidental }\end{array}$ & yes & no & 2 & low \\
\hline
\end{tabular}

Q1 - is the phenomenon real or hypothetical? (1 - real, 0 - hypothetical); Q2 - did the phenomenon occur in the last 20 years? (1 - yes, 0 - no); Q3 - is the phenomenon permanent or incidental? (1 - permanent, 0 - incidental); Q4 - did the phenomenon cause material damage? (1 - yes, 0 - no); Q5 - have attempts been made to prevent the phenomenon? $(1-$ yes, 0 - no) * - even though earthquake effects have occured in the last 20 years it is stated here as hypothetical because the area of interest is considered as low-seismicity zone

- Hydrogeohazard - as outflow of groundwater at the cliff and in the colluvium becomes more intense, the risk of marine erosion will increase, and the rate of erosion and mass movements will be much higher. The barrier coast will be exposed to destructive processes from two directions: increased abrasion from the sea and erosion of dunes from the south, where a permanent floodplain may occur.

- The area of investigation is traditionally considered as a low-seismicity zone, but the occurrence of earthquakes that may influence the coastal zone cannot be completely excluded (as with the earthquake of September 2004).

- Interactions between different types of natural hazards may exacerbate the problem. The relationships between these processes, their connections and impacts are not fully understood and should be the subject of further research.
- Even in locations where the level of hazard is potentially low (i.e. a non-tidal sea, with low seismicity) some serious threats can be identified and thus their socioeconomic impact should be also taken into consideration during spatial planning and the preparation of adaptation and risk reduction strategies.

Acknowledgements. The authors are grateful to the reviewers for valuable remarks and suggestions that allowed improving the manuscript. The authors would also like thank all those who kindly helped during the studies and in the preparation of this paper, especially to L. Mil and all those who put in a huge effort during the offshore survey. The studies were funded by the National Fund of Environmental Protection and Water Management.

\section{REFERENCES}

Assinovskaya, B.A., Ovsov, M.K., 2008. Seismotectonic position of the Kaliningrad September 21, 2004, earthquake. Izvestiya, Physics of the Solid Earth, 44: 717-727.

Bunke, D., Leipe, T., Moros, M., Morys, C., Tauber, F., Virtasalo, J.J., Forster, S., Arz, H.W., 2019. Natural and anthropogenic sediment mixing processes in the south-western Baltic Sea. Frontiers in Marine Science, 6: 667.

Camargo, J.M.R., Silva, M.V.B., Ferreira Junior, A.V., Araujo, T.C.M., 2019. Marine geohazards: a bibliometric-based review. Geosciences, 9: 100.

Culshaw, M.G., 2018. Geohazards. In: Encyclopedia of Engineering Geology. Encyclopedia of Earth Sciences Series (eds. P. Bobrowsky and B. Marker). Springer, Cham.

Deng, J., Harff, J., Giza, A., Hartleib, J., Dudzińska-Nowak, J., Bobertz, B., Furmańczyk, K., Zolitz, R., 2017. Reconstruction of coastline changes by the comparisons of historical maps at the Pomeranian Bay, Southern Baltic Sea. Coastal Research Library, 19: 271-287.

Didier, D., Baudry, J., Bertchez, P., Dumont, D., Sadegh, M., Bismuth, E., Bandet, M., Dugas, S., Sevigny, C., 2019. Multihazard simulation for coastal flood mapping: bathtub versus nu- merical modelling in an open estuary, Eastern Canada. Journal of Flood Risk Management, 12: 1-19.

Earlie, C., Masselink, G., Russel, P., 2018. The role of beach morphology on coastal cliff erosion under extreme waves. Earth Surface Processes and Landforms, 43: 1213-1228.

Furmańczyk, K., Musielak, S., 1999. Circulation systems of the coastal zone and their role in south Baltic morphodynamic of the coast. Quaternary Studies in Poland, Special Issue: 91-94.

Furmańczyk, K., Musielak, S., 2002. Important features of coastline dynamics in Poland: "nodal points" and "gates" In: Baltic Coastal Ecosystems, Structure, Function and Coastal Zone Management (eds. G. Schernewski and U. Schiewer): 141-147. Springer.

Hansen, W.R., 1965. Effects of the earthquake of March 27, 1964, at Anchorage, Alaska The Alaska Earthquake, March 27, 1964, Effects on Communities. U.S. Geological Survey Professional Paper, 542, chapter A.

Harff, J., Mayer, M., 2011. Coastline of the Baltic Sea - zone of competition between geological processes and a changing climate: examples from the Southern Baltic. In: The Baltic Sea Ba- 
sin (eds. J. Harff, B. Bjoeck and P. Hoth): 149-164. Central and Eastern European Development Studies, Springer.

Lee, E.M., 2008. Coastal cliff behaviour: observations on the relationship between beach levels and recession rates. Geomorphology, 101: 558-71

Lidzbarski, M., Taranawska E., 2015. The role of the hydrogeological research on cliff coast in diagnosis and forecasting of the geological hazards (in Polish with English summary). Przegląd Geologiczny, 63: 901-907.

Meier, H.E.M., Broman, B., Kjellstrom, E., 2004. Simulated sea level in past and future climates of the Baltic Sea. Climate Research, 27: 59-75.

Miller, D.J., 1960. The Alaska earthquake of July 10, 1958: giant wave in Lituya Bay. Bulletin of the Seismological Society of America, 50: 253-266.

Mörner, N.A., 2004. Active faults and paleoseismicity in Fennoscandia, especially Sweden. Primary structures and secondary effects. Tectonophysics, 380: 139-157.

Mörner, N.A., 2008. Tsunami events within the Baltic. Polish Geological Special Papers, 23: 71-76.

Moskalewicz, D., Sokołowski, R., Fedorowicz, S., 2016. River response to climate and sea level changes during the Late Saalian/Early Eemian in northern Poland - a case study of meandering river deposits in the Chłapowo cliff section. Geologos, 22: $1-14$.

Moskalewicz, D., Szczuciński, W., Mroczek, P., Vaikutiene, G., 2020. Sedimentary record of historical extreme storm surges on the Gulf of Gdańsk coast, Baltic Sea. Marine Geology, 420: 106084.

Orviku, K., Tonisson, H., Kont, A., Suuroja, S., Anderson, A., 2013. Retreat rate of cliffs and scarps with different geological properties in various locations along the Estonian coast. Journal of Coastal Research, Special Issue, 65: 552-557.

Palginõmm, V., Orviku, K., Suursaar, U., Kont, A., Tőnisson, H., Rivis, R., 2018. Lessons learned from record-high storm surges and associated inundations in Pärnu, SW Estonia. Journal of Coastal Research, 85: 1391-1395.

Paprotny, D., Kreibich, H., Morales-Napoles, O., Terefenko, P., Schrotter, K., 2020. Estimating exposure of residential assets to natural hazards in Europe using open data. Natural Hazards and Earth System Science, 20: 323-343.

Pawłowski, S., 1922. Caracteristique morphologique des cotes PoIonaises (in Polish with French summary). Towarzystwo Przyjaciół Nauk o Ziemi, Poznań.

Piotrowski, A., Szczuciński, W., Sydor, P., Kotrys, B., Rzodkiewicz, M., Krzymińska, J., 2017. Sedimentary evidence of extreme storm surge or tsunami events in the southern Baltic Sea (Rogowo area, NW Poland). Geological Quarterly, 61 (4): 973-986.

Rudowski, S., 1965. Geology of the Keppa Swarzewska Cliff (in Polish with English summary). Rocznik Polskiego Towarzystwa Geologicznego, 35: 301-318.

Ryabchuk, D., Spiridonov, M., Zhamoida, V., Nesterova, E., Sergeev, A., 2012. Long term and short term coastal line changes of the Eastern Gulf of Finland. Problems of coastal erosion. Journal of Coastal Conservation, 16: 233-242.

Spiridonov, M., Ryabchuk, D., Zhamoida, V., Sergeev, A., Sivkov, V., Boldyrev, V., 2011. Geological hazard potential at the Baltic Sea and its coastal zone: examples from the Eastern Gulf of Finland and the Kaliningrad area. In: The Baltic Sea Basin (eds. J. Harff, S. Bjorck and P. Hoth): 337-364. Springer.

Staud, M., Kordalski, Z., Żmuda, J., 2006. Assessment of modelled sea level rise impacts in the Gdańsk region, Poland. Geological Survey of Finland, Special Paper, 41: 121-130.

Uścinowicz, G., Szarafin, T., 2018. Short-term prognosis of development of barrier-type coasts (Southern Baltic Sea). Ocean and Coastal Management, 165: 258-267.

Uścinowicz, G., Kramarska, R., Kaulbarsz, D., Jurys, L., Frydel, J., Przezdziecki, P., Jegliński, W., 2014. Baltic Sea coastal erosion; a case study from the Jastrzebia Góra region. Geologos, 20: 259-268.

Uścinowicz, G., Jurys, L., Szarafin, T., 2017. The development of unconsolidated sedimentary coastal cliffs (Pobrzeże Kaszubskie, Northern Poland). Geological Quarterly, 61 (2): 491-501.

Uścinowicz, G., Szarafin, T., Jurys, L., 2019. Tracking cliff activity based on multi temporal digital terrain models - an example from the southern Baltic Sea coast. Baltica, 32: 10-212.

Uścinowicz, S., Zachowicz, J., Graniczny, M., Dobracki, R., 2004. Geological structure of the southern Baltic coast and related hazards. Polish Geological Institute Special Papers, 15: 61-68.

Uścinowicz, S., Miotk-Szpiganowicz, G., Gałka, M., Pawlyta, J., Piotrowska, N., Pomian, I., Witak, M., 2013. The rise, development and destruction of the medieval port of Puck in the light of research into palaeoclimate and sea level change. Archaeologia Polona, 49: 87-104.

Uścinowicz, S., Jegliński, W., Miotk-Szpiganowicz, G., Nowak, J., Paczek, U., Przezdziecki, P., Szefler, K., Poręba, G., 2014. Impact of sand extraction from the bottom of the southern Baltic Sea on the relief and sediments of the seabed. Oceanologia, 56: 857-880.

Valdmann, A., Käärd, A., Kelpđaitë, L., Kurennoy, D., Soomere, T., 2008. Marine coastal hazards for the eastern coasts of the Baltic Sea. Baltica, 21: 3-12.

Wentworth, C.K., 1922. A scale of grade and class terms for clastic sediments. The Journal of Geology, 30: 377-392.

Widera, M., 2019. What can be learned about the deposition and compaction of peat from the Miocene lignite seam exposed in the Chłapowo cliff on the Polish coast of the Baltic Sea? Geology, Geophysics and Environment, 45: 111-119.

Wiejacz, P., 2006. The Kaliningrad earthquakes of September 21, 2004. Acta Geodynamica et Geomaterialia, 3: 7-16.

Yonggang, J., Chaoqi, Z., Liping, L., Dong, W., 2016. Marine geohazards: review and future perspective. Acta Geologica Sinica, 90: 1455-1470.

Zeidler, R., 1995. Vulnerability of Poland's coastal areas to sea level rise. Journal of Coastal Research, Special Issue, 22: 99-109. 